\title{
Deconvoluting the complexity of autophagy and Parkinson's disease for potential therapeutic purpose
}

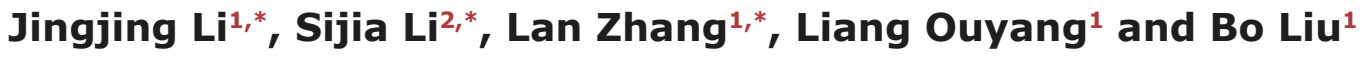 \\ ${ }^{1}$ State Key Laboratory of Biotherapy and Cancer Center, Collaborative Innovation Center of Biotherapy, West China Hospital, \\ Sichuan University, Chengdu, China \\ ${ }^{2}$ State Key Laboratory of Stomatology, West China Hospital of Stomatology, Sichuan University, Chengdu, China \\ * These authors have contributed equally to this work \\ Correspondence to: Bo Liv, email: liubo2400@scu.edu.cn
}

Liang Ouyang, email: ouyangliang@scu.edu.cn

Keywords: Parkinson's disease (PD), autophagy, a-synuclein, LRRK2, PD therapy

Received: July 31,2015 Accepted: September 12, $2015 \quad$ Published: September 22, 2015

This is an open-access article distributed under the terms of the Creative Commons Attribution License, which permits unrestricted use, distribution, and reproduction in any medium, provided the original author and source are credited.

\section{ABSTRACT}

Parkinson's disease (PD) is a neurodegenerative disorder characterized by the preferential death of dopaminergic neurons. In the past two decades, great progress has been made toward understanding the pathogenesis of PD; however, its precise pathogenesis still remains unclear. Recently, accumulating evidence has suggested that macroautophagy (herein referred to as autophagy) is tightly linked to PD. Dysregulation of autophagic pathways has been observed in the brains of PD patients and in animal models of PD. More importantly, a number of PD-associated proteins, such as a-synuclein, LRRK2, Parkin and PINK1 have been further revealed to be involved in autophagy. Thus, it is now acknowledged that constitutive autophagy is essential for neuronal survival and that dysregulation of autophagy leads to PD. In this review, we focus on summarizing the relationships amongst PD-associated proteins, autophagy and PD. Moreover, we also demonstrate some autophagymodulating compounds and autophagic microRNAs in PD models, which may provide better promising strategies for potential PD therapy.

\section{INTRODUCTION}

Parkinson's disease is the second most common neurodegenerative disease, which is mainly characterized by the progressive loss of dopaminergic and non-dopaminergic neurons, and the development of intracellular aggregates of the protein $\alpha$-synuclein. The majority of PD is sporadic, while approximately 5-10\% of cases are inherited through PD-related genes $[1,2]$. Global disease burden for PD is increasing significantly in recent years, with all ages deaths (thousands) rises by 139.8 (77.36 to 156.99$) \%$ from 43.7 (38.3 to 55.1 ) to 102.5 (79.3 to 112.6 ) and age-standardized death rate (per $100000)$ rises by $28.2 \%$ ( -0.42 to 37.83$)$ from 1.5 (1.3 to 1.9 ) to 1.8 (1.4 to 2.0) between 1990 and 2013 [3]. With the growing ageing population, the number of people with PD globally is projected to be at least 8.7-9.3 million by 2030 [4]. In clinical, PD is characterized by the core motor symptoms collectively called parkinsonisms, including resting tremor, bradykinesia, muscle rigidity, postural instability and gait impairment, and it is also accompanied by a range of nonmotor symptoms, including constipation, urinary symptoms, sleep disorder, and dementia [5, 6]. In pathology, PD is featured by progressive degeneration not only within the dopaminergic nigrostriatal system, which leads to loss of dopamine in the striatum and is responsible for the main motor symptoms, but also by implication of a range of other neuronal systems and organs [7]. These lesions are accompanied by widespread occurrence of Lewy bodies (LBs) and Lewy neurites (LNs) composed of abnormal, post-translationally modified, and aggregated form of $\alpha$-synuclein, the major protein marker and pathological hallmark of PD [6]. Nowadays, multiple methods are applied in PD treatment, including medications, surgery, deep brain stimulation and multidisciplinary management, which substantially provide relief from the symptoms and improve quality of life and functional capacity. However, PD is still an 
progressive disease with no cure [8].

Recently, increasing evidence suggest that autophagy is closely related to the pathogenesis of PD and investigations on autophagic pathways in PD models may provide new clues on PD therapy $[9,10]$. Autophagy is an evolutionarily conserved catabolic process that mediates the degradation of long-lived proteins and dysfunctional or superfluous organelles in cells, and it is induced by various stressful conditions such as limited nutrients, low oxygen levels, and decreased energy supply [11]. In general, autophagy can be divided into three main types: macroautophagy, microautophagy, and chaperone-mediated autophagy (CMA), based on how cargo is delivered to the lysosome. In CMA, chaperone proteins mediate this process by binding to cytosolic substrates that enter the lysosome through interaction with a receptor/ channel on the lysosomal membrane [12]. Microautophagy refers to the process of direct uptake of cytoplasmic materials at the lysosome surface by invagination of the lysosome membrane. After vesicles containing the cytosolic substrates pinch off into the lysosomal lumen, they are rapidly degraded [13]. During macroautophagy, portions of the cytoplasm are engulfed by a double-membrane phagophore that expands into a cytosolic vesicle called an autophagosome, and then the autophagosome fuses with a lysosome to form an autolysosome, which degrades the macromolecules [14]. Among the three types of autophagy, macroautophagy is the best characterized process and will be hereafter be referred to as autophagy. Dysregulation of autophagic pathways has been observed in the brains of PD patients and in PD animal models, and a number of PD-associated genes have been reported to impair or induce autophagy in PD $[15,16]$, indicating the emerging role of autophagy in this disease. In particular, autophagy modulation has become a promising strategy in PD area and identification of targets in autophagy pathways is in urgent need.

\section{AUTOPHAGY AND PARKINSON'S DISEASE (PD)}

\section{Molecular mechanisms of autophagy}

Autophagy includes five phases: initiation, elongation, autophagosome formation, fusion, and autolysosome formation. The formation of autophagosomes is initiated in mammalian cells primarily by the Unc51-like kinase 1 (ULK1) complex containing ULK, Atg13, FIP200, and Atg101 [17,18]. Activation of this complex can be inhibited by mammalian target of rapamycin (mTOR) complex 1, which is a master negative regulator of autophagy in several pathways $[19,20]$. Another complex involved in the initiation of autophagy is the class III phosphatidylinositol 3-kinase (PtdIns3K)/
Vps34 complex I containing Beclin-1, Atg14 and Vps15 [21]. Elongation and maturation of autophagosomes involves two ubiquitin-like conjugation systems, the microtubule-associated protein 1 light chain 3 (LC3) system and the $\operatorname{Atg} 12$ system. $\operatorname{Atg} 12$ is conjugated to Atg 5 by Atg7 (E1 enzyme) and Atg10 (E2 enzyme). The Atg12-Atg5 heterodimer interacts with $A \operatorname{tg} 16 \mathrm{~L}$, and this complex promotes elongation of the autophagic membrane $[22,23]$. The full-length LC3 precursor is cleaved by Atg4B, forming LC3I. After autophagy is induced, LC3I is conjugated with phosphatidylethanolamine (PE) by Atg7 (E1 enzyme) and Atg3 (E2 enzyme). PE-conjugated LC3 becomes an insoluble form (LC3-II) that is stably inserted into the autophagosomal membrane [24]. Other proteins, including protein kinase A, AMPK/Snf1 and Pho85 regulate autophagy in response to various types of stress [25].

\section{Autophagy in PD}

Much evidence indicates that autophagy can be involved in PD. First clue for an implication of the autophagy-lysosomal pathway in PD was presented by a pathological study that detected autophagic vacuoles accumulation in the substantia nigra of PD patients [26]. Recent studies demonstrate the association of autophagic signal molecules with $\alpha$-synuclein pathology in PD, confirming that defects in the autophagy pathway are correlated with neurodegeneration in PD [27, 28]. In additional, inactivation of autophagy by deleting of the essential autophagy gene Atg7 in animal models predisposes to PD-like pathology, further verifying the neuroprotective role of autophagy in the pathogenesis of PD [29]. Furthermore, numerous studies show that the application of autophagy enhancers attenuate PDrelated dopaminergic neurodegeneration, both in vitro and in vivo, supporting the potential therapeutic effects of autophagy modulators in PD treatment [30-32]. Also, treatment of mesenchymal stem cells, which significantly enhances autophagy and impairs $\alpha$-synuclein expression in cellular and animal models of PD, leads to increased neuronal survival against environmental neurotoxins [33]. Inversely, several other researches also report the possible harmful role of autophagy in PD models. PD related mutants like A53T $\alpha$-synuclein and G2019S LRRK2 lead to cellular damage via the enhancement of autophagy [34, 35]. Also, some autophagy regulative chemicals such as 6-hydroxydopamine (6-OHDA) and 1-methyl-4-phenyl1,2,3,6-tetrahydropyridine (MPTP), are correlated with cell toxicity caused by autophagy, which can be ameliorate by autophagy inhibition [36-38]. Collectively, such results strongly suggest that dysregulation of autophagy is related to PD, although whether such dysregulation of autophagy is the cause or the consequence of PD pathology remains unclear and needs more investigation. Based on a number of previous researches, modulating autophagy 
either by compounds or siRNAs in some PD models in which autophagy was dysregulated can help alleviate the symptoms. Of note, one of those crucial factors result in autophagy dysregulation in PD could be genetic factors, such as SNCA and LRRK2. Mutant or over-expression of such PD-related genes is reported to regulate autophagy either positively or negatively, which may be part of pathogenesis of PD (Table.1). Therefore, it is significant to explore the complexity of these genes/proteins and autophagy, which could shed light on the etiology and therapeutic strategies.

\section{PD-RELATED ARE INVOLVED IN AUTOPHAGY MODULATION}

\section{- -synuclein}

$\alpha$-synuclein levels are considered a major determinant of its neurotoxic potential, and cytoplasmic $\alpha$-synuclein aggregates, referred to as Lewy bodies, are pathological hallmarks of PD [39]. A leading paradigm in PD research suggests that $\alpha$-synuclein accumulation, resulting from its overexpression or lack of degradation, is one of the important mechanisms causing degeneration of dopaminergic neurons [40]. PARK1- and PARK4linked PD, which is caused by mutations of wild-type SNCA ( $\alpha$-synuclein) gene, is an autosomal dominant one. PARK1 is caused by missense mutations and PARK4 by multiplications of $\alpha$-synuclein. Three missense mutations, (A53T, A30P and E46K), in addition to two gene multiplications (duplications, triplications) of the SNCA have been described so far [41-45]. Even sporadic PD cases were reported to be genetically linked to $\alpha$-synuclein polymorphisms, which modulate $\alpha$-synuclein transcription [46]. Several post-translational modifications such as phosphorylation, nitration, ubiquitination, oxidation, and dopamine-dependent adduct formation are related to the toxic forms of $\alpha$-synuclein.

$\alpha$-synuclein levels are closely connected with autophagy in recent studies. $\alpha$-synuclein occurs natively as a helically folded tetramer, with a great lipid binding capacity, and destabilization of the helically folded tetramer results in $\alpha$-synuclein misfolding and aggregation found in PD and other human synucleinopathies [47]. $\alpha$-synuclein is degraded by both ubiquitin-proteasome system (UPS) and the autophagy-lysosomal pathway (ALP), the latter of which consists of CMA and autophagy [48]. Increased levels of $\alpha$-synuclein or modified forms of the protein prevents its degradation by CMA and UPS, resulting in its toxic aggregation in the cytoplasm and contributing to PD pathogenesis $[49,50]$. The autophagy pathway may compensate for the lack of UPS and CMAmediated degradation and stimulation of autophagy through pharmacological or molecular means leads to increased clearance of $\alpha$-synuclein and thus neuroprotective, but autophagic cell death may also occur under stressful conditions [51-53]. Importantly, excessive levels of $\alpha$-synuclein leads to significant inhibition of autophagy, thus a vicious circle is formed and this leads to uncontrolled accumulation of $\alpha$-synuclein and causes neuronal dysfunction and degeneration (Figure.1) [5457]. Such evidence indicates that activation of the compensatory way of $\alpha$-synuclein degradation, i.e. autophagy, to increase clearance of disease-causing proteins thus protecting nerons may be a potent strategy to alleviate PD or other synucleinopathies.

On the other hand, several studies suggest that $\alpha$-synuclein and its mutants may also influence autophagy modulation in PD, which complicating the issue. Using a transgenic mouse line with human $\alpha$-synuclein A53T over-expression specifically in dopamine (DA) neurons, researchers uncovered the role of $\alpha$-synuclein in mitochondria and mitophagy impairments. They observed three clearly defined stages of pathology progression, which indicates that mitochondria and mitophagy impairments might be the cause rather than consequence of neurodegeneration in the $\mathrm{DA}_{\mathrm{SYN} 53}$ mice. $\alpha$-synuclein may target mitochondria and induces mitochondriaspecific macroautophagy (termed mitophagy). Both the immunofluorescence and immuno-EM data support the physical localization of human $\alpha$-synuclein within mitochondria in DA neurons of the $\mathrm{DA}_{\mathrm{SYN53}}$ mice [58]. Additionally, it has been reported that $\alpha$-synuclein contains a cryptic mitochondria targeting signal on its $\mathrm{N}$ terminus [59]. It is very likely that $\alpha$-synuclein may not impair mitochondria functions under normal conditions, but the functional disturbance of mitochondria by $\alpha$-synuclein may emerge during aging or under pathological conditions [60]. In PD patients carrying $\alpha$-synuclein gene multiplication mutations, the over-expressed $\alpha$-synuclein may increase its mitochondria localization and functional disturbance [61]. In the $\mathrm{DA}_{\mathrm{SYN53}}$ mice, DA neurons exhibit mitochondria fragmentation and prominent intracellular mitochondrial inclusions, but the general autophagy activity is not significantly changed, suggesting that mitophagy is mobilized to specifically remove $\alpha$-synuclein-damaged mitochondria without affecting general bulk macroautophagy [58]. Inversely, accumulating evidence also suggests that accumulation of A53T $\alpha$-synuclein impairs autophagy. For instance, A53T $\alpha$-synuclein over-expression impairs autophagy in SH-SY5Y cells and upregulates mammalian target of rapamycin (mTOR)/p70ribosomal protein S6 kinase (p70S6K) signaling, which is the classical suppressive pathway of autophagy. Silence of mTOR by mTOR siRNA improves the autophagy level and decreases the accumulation of $\alpha$-synuclein [62]. These evidence show that mTOR/p70S6K signaling plays a critical role in A53T induced disruption of autophagy, making 
Table 1: PD-associated genes/proteins and their roles in autophagy

\begin{tabular}{|c|c|c|c|c|c|}
\hline $\begin{array}{r}\text { PARK } \\
\text { locus }\end{array}$ & Gene & Clinical feature & Pathology & \begin{tabular}{|c|} 
Role of \\
autophagy
\end{tabular} & Reference \\
\hline PARK1/4 & SNCA & $\begin{array}{|ccc|}\text { Typical } & \begin{array}{r}\text { PD } \\
\text { dementia }\end{array} & \text { common } \\
\end{array}$ & Lewy bodies & Negative & {$[39-48]$} \\
\hline PARK2 & Parkin & $\begin{array}{l}\text { Early onset, slowly progressing, } \\
\text { usually with sleep benefit }\end{array}$ & Lewy bodies rarely & Positive & {$[82-87]$} \\
\hline PARK5 & UCH-L1 & Late onset & Unknown & Negative & {$[104,105]$} \\
\hline PARK6 & PINK1 & $\begin{array}{l}\text { Early onset, slowly progressing, } \\
\text { usually with sleep benefit }\end{array}$ & $\begin{array}{l}\text { One case with Lewy } \\
\text { bodies }\end{array}$ & Positive & [88-93] \\
\hline PARK7 & DJ-1 & Early onset & Unknown & Dual & [97-103] \\
\hline PARK8 & LRRK2 & Late onset & Usually Lewy bodies & Dual & [83-87] \\
\hline PARK9 & ATP13A2 & $\begin{array}{c}\text { Early-onset, } \\
\text { with Kufor-Rakeb syndrome }\end{array}$ & Unknown & Positive & [106-108] \\
\hline
\end{tabular}

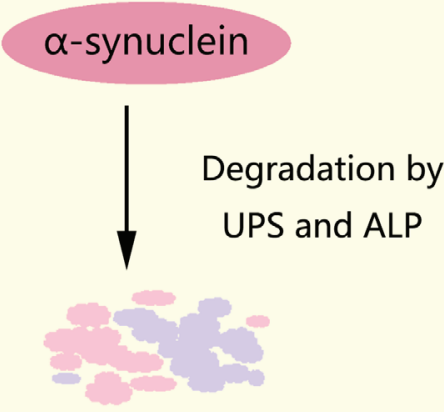

Normal turnover

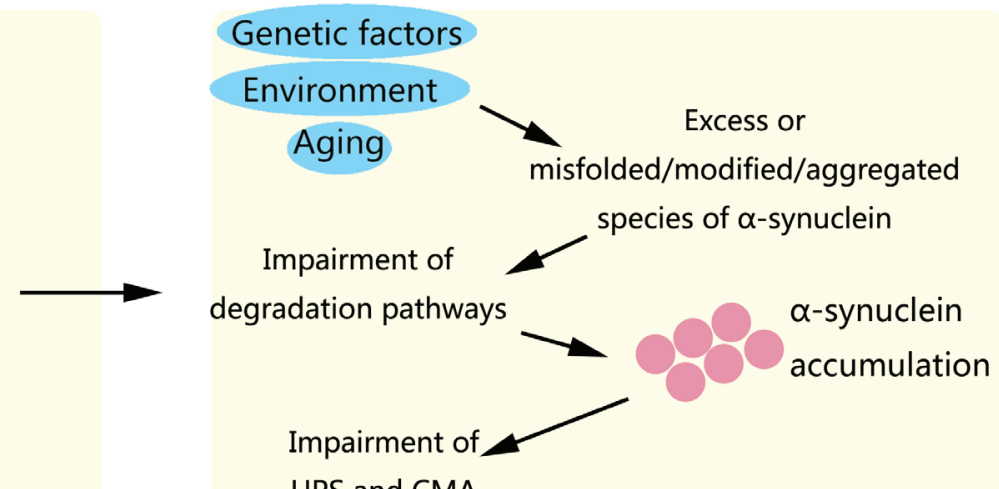

UPS and CMA

A

Excess or

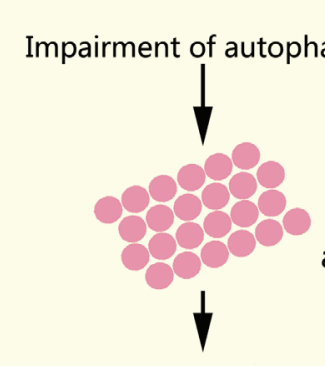

Neuronal

Uncontrolled

$\alpha$-synuclein

accumulation

misfolded/modified/aggregated species of $\alpha$-synuclein

Early disease stage

dysfunction \& degeneration

\section{Late disease stage}

Degradation

\section{Compensatory stage}

Figure 1: $\alpha$-synuclein pathology in PD. The successive dysfunction of protein degradation pathways is crucial in $\alpha$-synuclein pathology, neuronal dysfunction and degeneration. A. $\alpha$-synuclein is regularly degraded via both UPS and ALP. B. In the early disease stage, primary impairment of degradation pathways induced by genetic, environmental and age-related factors further prevents the degradation of $\alpha$-synuclein by CMA and UPS and leads to its toxic aggregation in the cytoplasm. C. Afterwards, crosstalk among degradation pathways drives the induction of autophagy and temporarily compensate for degradation impairment. $\mathbf{D}$. In the late disease stage, $\alpha$-synuclein accumulation inactivates autophagy, leading to complete dysfunction of all protein degradation pathways and uncontrolled accumulation of $\alpha$-synuclein, which consequently contributes to neuronal dysfunction and degeneration featured in PD. 
it a possible target for PD therapy. Another mutation in the gene encoding $\alpha$-synuclein, E46K mutant are also associated with PD. Importantly, it has been reported that the overexpression of E46K mutant $\alpha$-synuclein impaired autophagy at an early stage of autophagosome formation via the c-Jun N-terminal kinase 1 (JNK1)-Bcl-2 but not the mTOR pathway in PC12 and HEK293 cells transfected with human E46K mutant $\alpha$-synuclein. Specifically, overexpressed E46K mutant $\alpha$-synuclein inhibited JNK1 activation, leading to a reduced $\mathrm{Bcl}-2$ phosphorylation and increased association between Bcl-2 and Beclin-1, further disrupting the formation of Beclin-1/hVps34 complex, which is essential for autophagy initiation. In addition, the vulnerability of cells to toxic insults were also increased in overexpressed E46K mutant, which may due to impaired autophagy [63]. Furthermore, other studies demonstrate that although $\alpha$-synuclein inclusions colocalize with essential components of autophagic pathways, such as p62 and LC3, they cannot be be effectively degraded by autophagy. Results from mammalian cells and transgenic mice suggest that over-expression of $\alpha$-synuclein compromises autophagy via Rabla inhibition, which results in the alteration of the autophagy protein Atg9 localization and the inhibition of autophagosome formation [10]. Although the link between $\alpha$-synuclein and autophagy in PD has not been fully uncovered, such results above demonstrate that autophagy modulation by specific targets in $\alpha$-synuclein related pathways can be a potent strategy for PD therapy.

\section{LRRK2}

Mutations of PARK8, the gene encoding leucinerich repeat kinase 2 (LRRK2), are linked to the most common autosomal dominant form of PD, and also some sporadic PD patients [64, 65]. Many LRRK2related mutations have been reported in PD patients, among which only 6 of these mutations (R1441C/G/H, Y1699C, I2020T and G2019S ) located in the central catalytic ROC-COR-kinase triple domain are clearly pathogenic [66, 67]. Some other LRRK2 variants (G2385R, R1628P) outside of the enzymatic domains represent risk factors for $\mathrm{PD}$, while the significance of other reported substitutions remains unclear $[66,68]$. Some evidence suggest that the wild-type LRRK2 protein is degraded by CMA, while the common LRRK2 G2019S mutation impairs this degradation. In addition, a wide variety of studies suggest that LRRK2 is also connected with autophagy. However, the dysregulation of autophagy may be either positive or negative in different mutations and cellular systems. The absence of LRRK2 causes impairment of autophagy-lysosomal pathway, as indicated by accumulation of lipofuscin granules as well as altered levels of autophagy marker proteins LC3-II and p62 [69]. LRRK2 has also been shown to present on autophagosomal membranes isolated from activated macrophage cells, further supporting its regulative role in autophagy [70]. Expression of the R1441C LRRK2 causes impaired autophagic balance, while LRRK2 knockdown increases autophagic activity and prevents cell death induced by autophagy inhibition under starvation conditions [71]. The G2019S mutation was reported to induce striking augmented autophagy in cell experiments, possibly through a mechanism involving excessive mitochondrial fission mediated by dynamin-related protein1 (Drp1) phosphorylation [72-74]. A recent study suggested an effect of the LRRK2 G2019S mutation on induction of mitophagy by interacting with $\mathrm{Bcl}-2$ [75]. Moreover, another study also shows that autophagy deficiency causes increased LRRK2 protein levels and its accumulation in brain [29]. Noticeably, PD patients with LRRK2 mutations frequently exhibit $\alpha$-synuclein toxicity in the form of Lewy bodies, in which LRRK2 is also present. On the one hand, increased expression of $\alpha$-synuclein protein has been detected in Y1699C or G2019S LRRK2 PD patient iPS-derived dopamine neurons, indicating the role of $\alpha$-synuclein in LRRK2 toxicity [76-78]. On the other hand, LRRK2 over-expression enhances $\alpha$-synuclein-mediated neuropathology by promoting the abnormal aggregation and toxicity of $\alpha$-synuclein, while $\alpha$-synuclein cytotoxicity was abrogated by genetic ablation of LRRK2 $[79,80]$. The absence of A53T $\alpha$-synuclein over-expression makes G2019S LRRK2 unable to cause $\alpha$-synuclein accumulation [80]. However, LRRK2associated PD is not always characterized by accumulation of $\alpha$-synuclein. It can be associated with deposition of MAPT/tau protein or ubiquitin-positive inclusions [81]. It was suggested that LRRK2 dysfunction may be upstream to the accumulation of $\alpha$-synuclein and MAPT, and that other genetic or environmental factors determine which pathology will develop [66]; however, more evidence is needed to support this hypothesis. Still, LRRK2 plays a critical role in pathogenesis of PD and is closely related to autophagy modulation in PD.

\section{PINK1 and parkin}

Mutants in two significant proteins, PINK1 and Parkin, are linked with young onset autosomal recessive PD. Parkin, an E3 ubiquitin ligase implicated in Parkinson's disease is encoded by the 12 exon PARK2 $[82,83]$. Over 100 mutations in Parkin have been reported, including missense and nonsense mutations, exonic deletions and multiplications of exons [84-87]. The PARK6 gene contains 8 exons and encodes PINK1, a mitochondrial kinase involved in the mitochondrial dysfunction in the PD pathophysiology [88, 89]. Unlike Parkin, most PINK1 mutations reported are missense and nonsense mutations [72, 90-93].

PINK1 together with Parkin is closely related to mitochondrial function, with PINK1 being upstream of Parkin. The protein sequence of PINK1 reveals a 
predicted C-terminal kinase domain and a mitochondrial targeting sequence at the $\mathrm{N}$ terminus. PINK1 accumulates specifically on damaged mitochondria. PINK1 is degraded rapidly and constitutively in healthy mitochondria, but the degradation of PINK1 is prevented when one mitochondrion becomes impaired, allowing PINK1 to accumulate on the outer membrane of the impaired mitochondrion. After PINK1 accumulation, PINK1 phosphorylates ubiquitin and Parkin to activate Parkin's E3 ligase activity. Parkin is an E3 ubiquitin ligase with an amino-terminal ubiquitin-like domain and a carboxylterminal ubiquitin ligase domain. Once activated, Parkin facilitates the mitochondrial clearance via ubiquitylation of specific mitochondrial proteins thereby recruiting autophagic adapters, such as p62 to execute final autophagy [89]. However, mutated forms of PINK1 and Parkin are unable to mediate this process, thus by impairing this process, PD-causing mutations of PINK1 and Parkin may impede mitophagy, cause the accumulation of defective mitochondria, potentially initiate apoptotic events, and, ultimately, lead to neurodegeneration in PD [94].

Moreover, PINK1 is recently reported to be of potential significance in autophagy regulation. By interacting with Beclin-1, PINK1 distinctly enhances both basal and starvation-induced autophagy, which is blocked by Beclin-1 knock down or by inhibition of the Beclin-1 partner Vps34. Conversely, mutant forms of PINK1, are either unable or less effective to promote autophagy, since they lack the ability to interact with Beclin-1 or have defective kinase activity [95]. A recent study demonstrates that PINK1 can interact with, and phosphorylate Bcl-xL, an anti-apoptotic protein of the Bcl-2 family also known to inhibit autophagy through its binding to Beclin-1, thus protecting against apoptotic cell death. However, PINK1dependent Bcl-xL phosphorylation does not interfere either with the release of Beclin-1 from Bcl-xL or the autophagy pathway in their results [96].

\section{OTHER PD-ASSOCIATED GENES/ PROTEINS IN AUTOPHAGY}

Mutations of PARK7/DJ-1 are causes of another young onset autosomal recessive PD. PARK7-linked PD is very rare with its clinical features similar to those of PARK2-linked PD. DJ-1 also implicated in autophagy, with its role still in debate. Early study has shown that loss of DJ-1 resulted in impaired basal autophagy and accumulation of defective mitochondria, which is connected with reduction in phosphorylated ERK2 [97, 98]. Conversely, other studies challenged these results showing that DJ-1 deficiency promotes an enhancement in autophagic activity, as an increase in autophagy markers was observed [99-101]. Another study suggests that DJ-1 may act to alter autophagy indirectly by maintain mitochondrial function during oxidative stress, to be specific, DJ-1 absence reduces NF- $\kappa \mathrm{B}$ signaling, which lessen NF- $\mathrm{BB}$-dependent suppression of autophagy via mTOR [102]. Additionally, inhibition of JNK pathway blocks autophagy activation induced by DJ-1 knockdown, indicating that DJ-1 regulates autophagy in a JNKdependent manner [103].

Mutations in UCH-L1 are associated with PARK5-linked PD, a very rare autosomal dominant PD. Autophagy is proved to be one of the major mechanisms that degrade UCH-L1 [104]. In addition, a recent study shows that UCH-L1 suppression activates the autophagic pathway and thus prevents $\alpha$-synuclein aggregates formation [105]. PARK9-linked PD represents an autosomal recessive disorder and the gene was identified as ATP13A2, which is also involved in autophagy regulation [106]. ATP13A2 is responsible for $\alpha$-synuclein clearance via the lysosome, and a failure in this process would lead to the toxic accumulation of $\alpha$-synuclein in the cytoplasm. Impaired autophagy and accumulation of $\alpha$-synuclein is observed in both ATP13A2 mutant or deficient cells and elevated ATP13A2 expression leads to reduction of intracellular $\alpha$-synuclein protein [107, 108]. Mutations of the glucocerebrosidase (GBA) gene represent the greatest genetic risk factor for PD [109]. GBA deficits are correlated with reduced GBA and $\alpha$-synuclein accumulation, as well as suppression of CMA pathways. However, there is no evidence so far indicating connections between GBA mutations and macroautophagy [110].

\section{MODULATION OF AUTOPHAGY FOR PD THERAPY}

PD is still an incurable disease affecting millions of people worldwide. Many treatment methods, including medications, surgery, deep brain stimulation and multidisciplinary management, are applied in current PD therapy and contribute to better symptom control and life quality [11]. As the etiology of PD remains largely unknown, the available therapeutic approaches of the disease are focused on neuroprotection for cells preservation and symptom control via increasing dopamine levels in involved brain areas. However, the dopamine-based strategy is accompanied by a series of side effects and can be ineffective, due to the possible habituation or dopaminergic neuron death [111]. In view of the increased global disease burden of PD and the deficiency of effective treatments, there is an increased urgency to explore novel therapeutic approaches for PD treatment, one of which is autophagy modulation. From what has been discussed before, it is clear that autophagy play a crucial part in PD, although whether it act as the cause or the result of onset of $\mathrm{PD}$ remains unknown. Still, it is worth noting that dysregulation of autophagic pathways has been observed in the brains of PD patients and in PD animal models, which may result 
Table 2: Autophagy-modulating compounds in potential PD therapy.

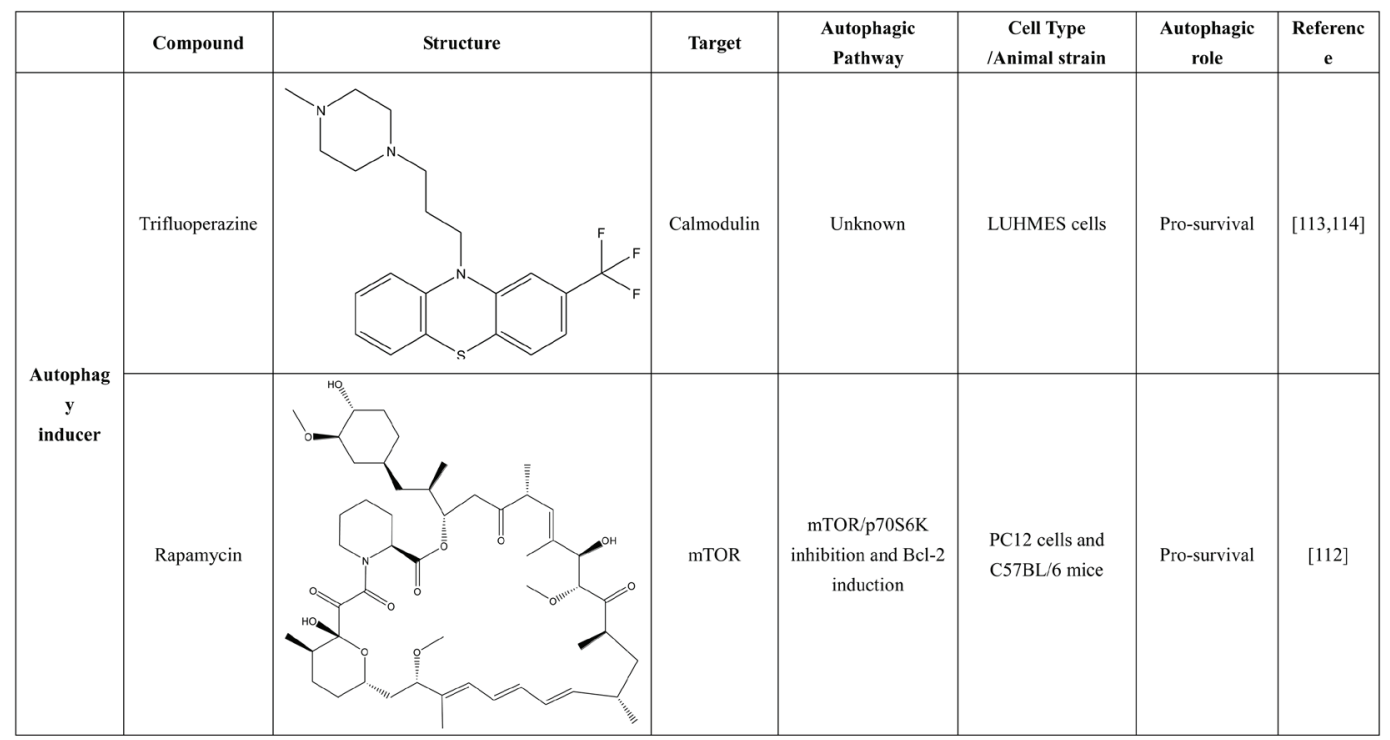

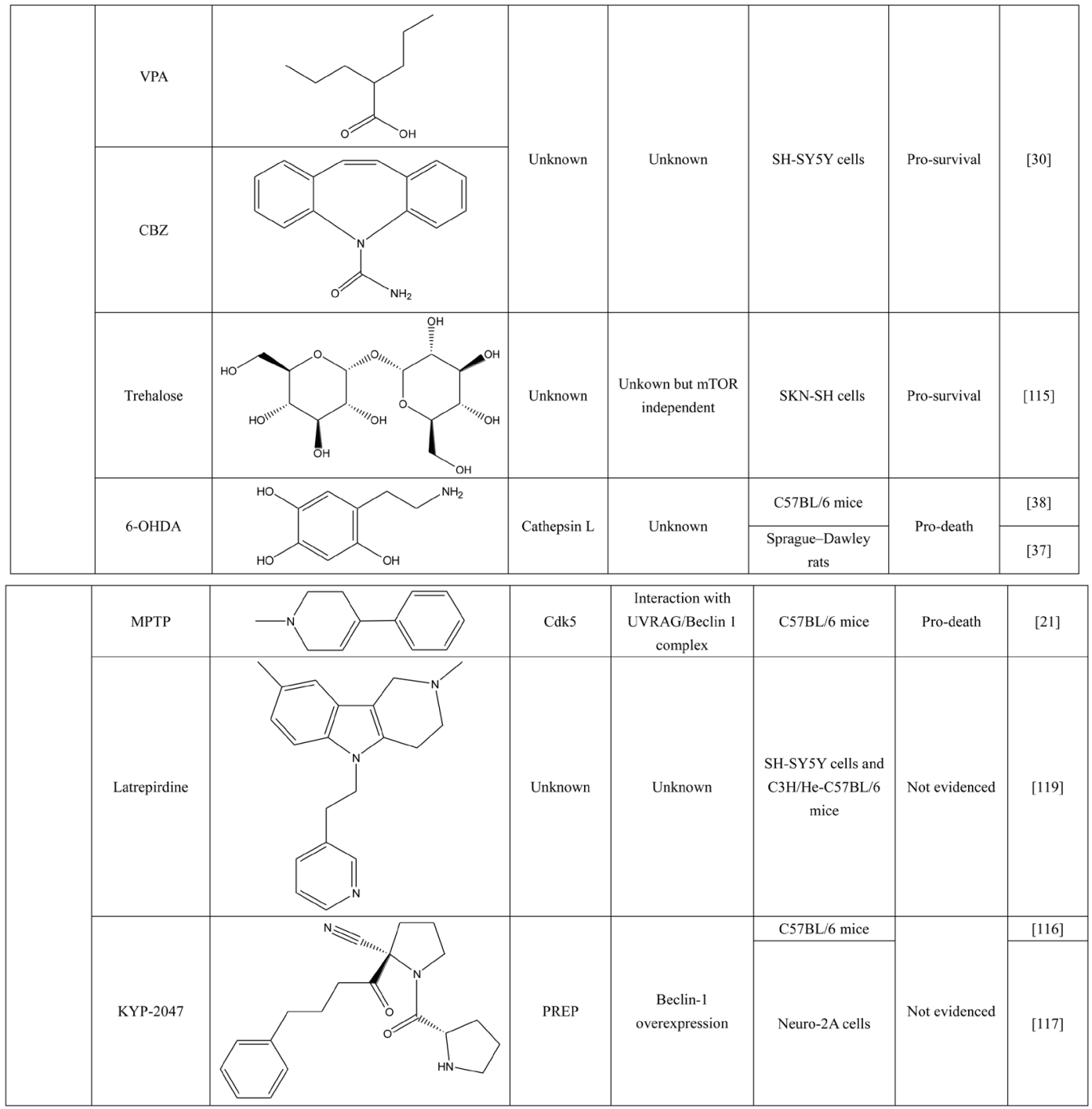



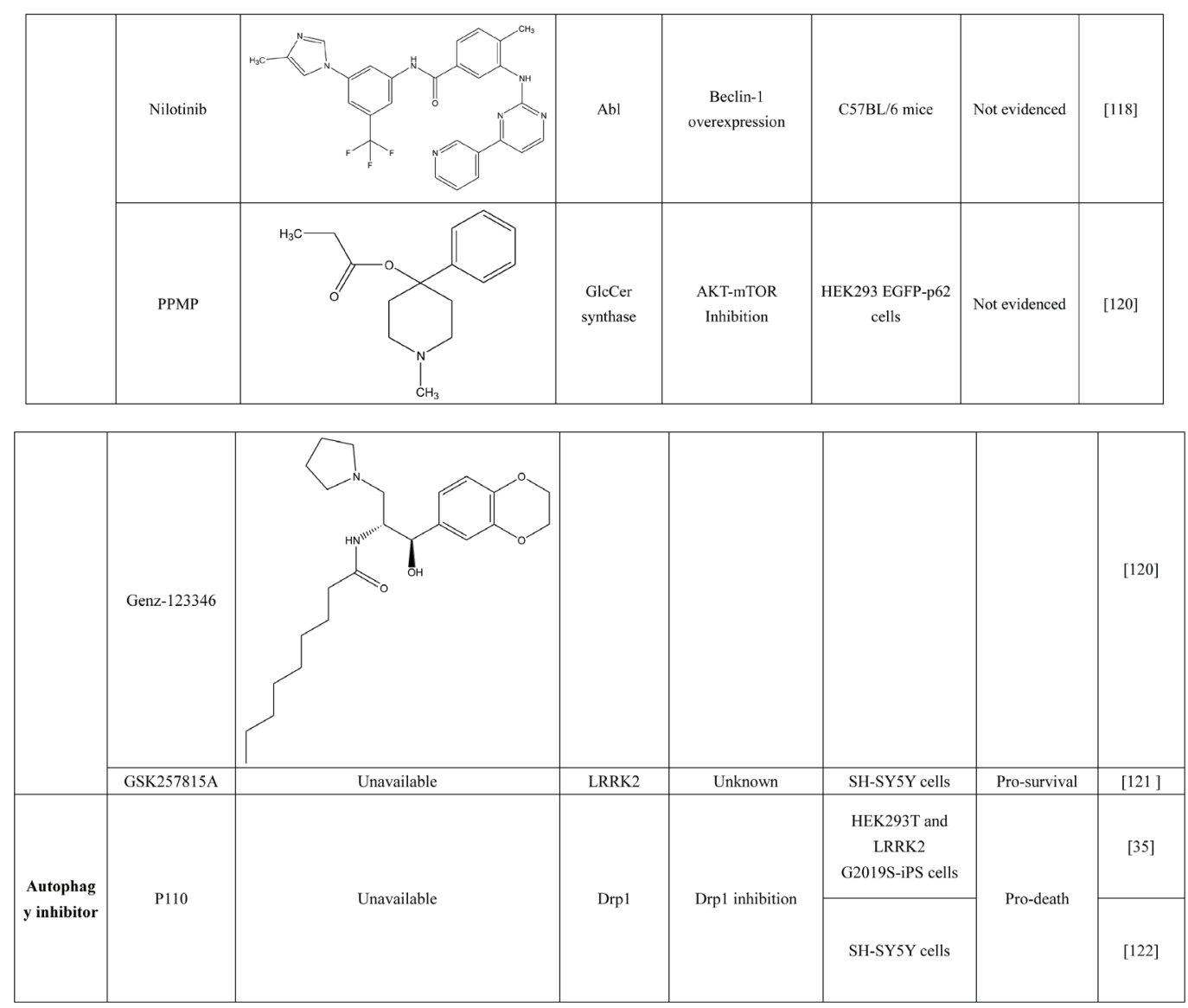

from over-expression or mutation of some key PD-related genes, such as SNCA, and modulation of autophagy help contribute to PD remission.

\section{AUTOPHAGY-MODULATING COMPOUNDS IN POTENTIAL PD THERAPY}

A number of compounds have been reported to regulate autophagy in PD models, and several of them relieved symptoms or improved cell viability (Table.2). Extensive researches are done detecting the link between PD and autophagy enhancers, which is suggested as cytoprotective in most results. A natural compound named curcumin, could efficiently reduce the accumulation of A53T $\alpha$-synuclein through downregulation of the mTOR/ p70S6K signaling and recovery of macroautophagy which was suppressed in SH-SY5Y cells [62]. Some other compounds exhibit ability to rescue neurons from toxin-mediated cell death. Rapamycin induces autophagy followed by mTOR/p70S6K inhibition and $\mathrm{Bcl}-2$ induction and shows its neuroprotective ability in lactacystin-induced neurodegeneration, both in vivo and in vitro [112]. The phenothiazine neuroleptic trifluoperazine activates autophagy in LUHMES neuron and rescues neurons from $\alpha$-synuclein-mediated cell death [113,
114]. Likewise, two autophagy enhancers, valproic acid (VPA) and carbamazepine (CBZ), strengthened SHSH5Y survival against rotenone toxicity [30]. Also, trehalose, a novel mTOR-independent autophagy inducer, accelerates the clearance of the $\mathrm{A} 30 \mathrm{P}$ and $\mathrm{A} 53 \mathrm{~T}$ mutants of $\alpha$-synuclein but not wild type $\alpha$-synuclein, and also protects neurons from staurosporine-induced cell death [115]. While the protective autophagy role in mentioned compounds above is evidenced by the opposite prodeath effect after autophagy suppression, studies in some other compounds strongly suggest the existence of protective autophagy, though without proving. A Prolyl oligopeptidase (PREP) inhibitor, 4-phenylbutanoyl-Lprolyl-2(S)-cyanopyrrolidine (KYP-2047), enhances autophagic clearance of $\alpha$-synuclein, both in vivo and in vitro, via a Beclin-1-dependent pathway [116,117]. The tyrosine kinase Abl inhibitor nilotinib, which is used in adult leukemia therapies, reaches the brain within US Food and Drug Administration approved doses, stimulates autophagic degradation of $\alpha$-synuclein, protects neurons, increases dopamine levels and thus improves motor performance in mice [118]. Similarly, Latrepirdine ameliorated the degradation of $\alpha$-synuclein in differentiated SH-SY5Y neurons, and in vivo in mouse brains, in parallel with enhanced autophagy [119]. Besides, two glucosylceramide (GlcCer) synthase inhibitors DL-threo-1-Phenyl-2-palmitoylamino-3- 
morpholino-1-propanol (PPMP) and Genz-123346 (Genz) exert their robust effects on autophagy enhancement in an AKT-mTOR-dependent manner and and reduces mutant $\alpha$-synuclein levels in neurons. Nonetheless, the prosurvival role of autophagy is not successfully confirmed by autophagy block, indicating that the autophagic degradation does not contribute to the decrease in mutant $\alpha$-synuclein[120]. Of note, an inhibitor of both wild-type and mutant LRRK2 forms, 2-arylmethyloxy-5-subtitutent$\mathrm{N}$-arylbenzamide (named GSK257815A), has been reported to induce protective autophagy in dopaminergic cell culture model SH-SY5Y [121].
In other cases, compounds are inversely concerned with cytotoxic mechanisms of autophagy in PD. 6-OHDA, one of the most commonly used neurotoxins for modeling degeneration of dopaminergic neurons in $\mathrm{PD}$, is able to induce autophagic cell death, which can be reverted by pretreated with autophagy inhibition by 3-methyladenine (3-MA) or AKT activation [37, 38]. MPTP also triggers neuronal loss with Cdk-5-associated autophagy activation [36]. The two compounds above are often used for building PD models but not for treatment. Another situation is that compounds may protect cells from death by inhibiting cytotoxic autophagy. For instance, a novel

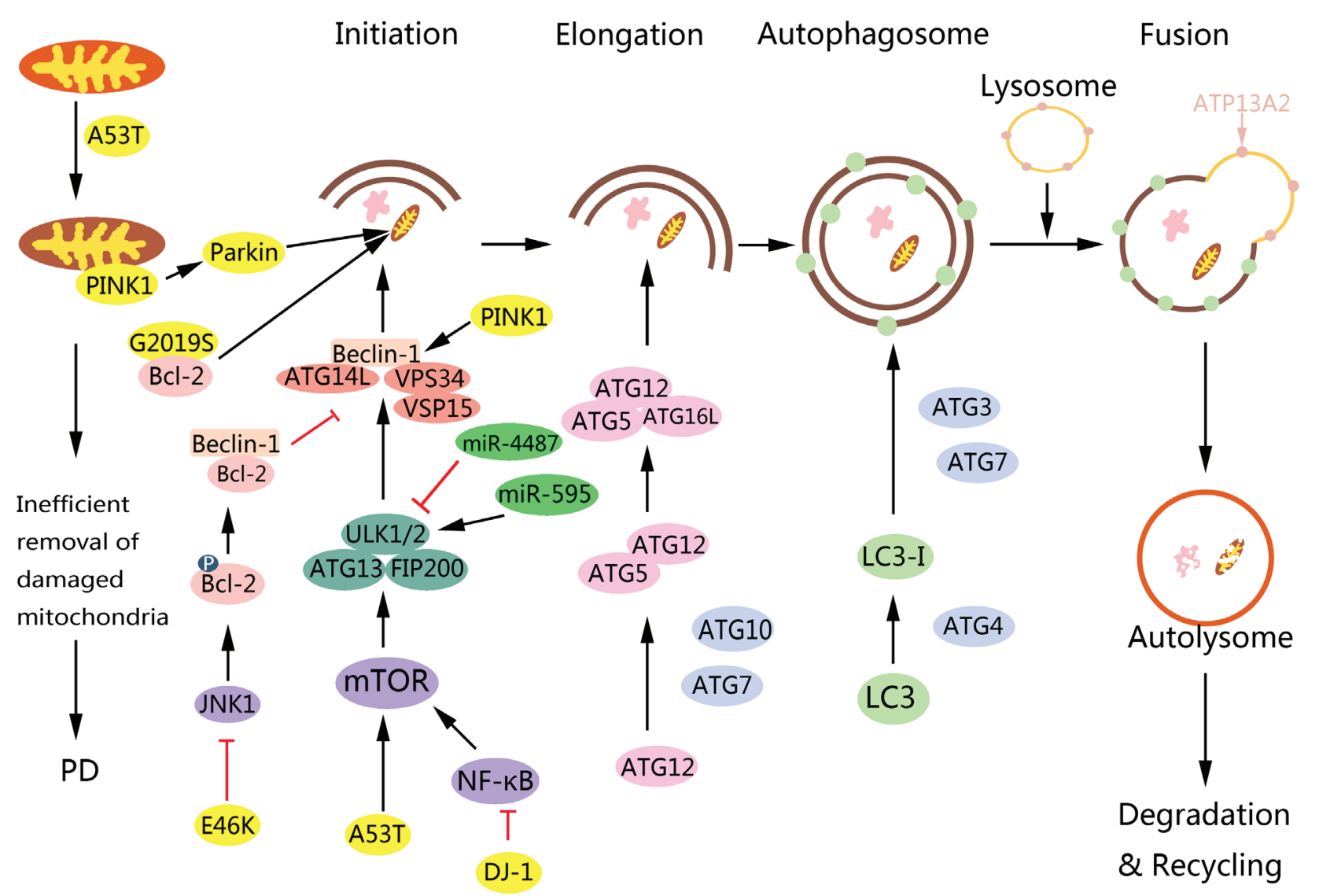

Figure 2: Role of PD-associated proteins in autophagy and targeting autophagy pathway for PD therapy. During aging or under pathological conditions, $\alpha$-synuclein A53T can cause mitochondria damage and induce mitophagy. However, damaged mitochondria cannot be removed efficiently through mitophagy, which contributes to PD. Also, A53T impairs autophagy in SH-SY5Y cells by upregulating mTOR signaling. E46K $\alpha$-synuclein impairs autophagy via JNK1-Bcl-2 but not the mTOR pathway in PC12 and HEK293 cells. LRRK2 can regulate autophagy either positively or negatively, while its molecular mechanism still remains unclear. According to a recent study, LRRK2 G2019S mutation can induce mitophagy by interacting with Bcl-2. Also, LRRK2 dysfunction may be upstream to $\alpha$-synuclein. PINK1 or parkin is indispensable for the proper autophagic removal of damaged mitochondria. PINK1 accumulates specifically on damaged mitochondria. After PINK1 accumulation, PINK1 phosphorylates ubiquitin and Parkin to activate Parkin's E3 ligase activity. Once activated, Parkin facilitates the mitochondrial clearance via ubiquitylation of specific mitochondrial proteins thereby recruiting autophagic adapters, such as p62 to execute final autophagy. Mutations of PINK1 and Parkin may impede mitophagy, cause the accumulation of defective mitochondria, potentially initiate apoptotic events, and ultimately lead to neurodegeneration in PD. In addition, PINK1 can enhance autophagy by interacting with Beclin-1. DJ-1 can alter autophagy via NF- $\kappa$ B signaling. ATP13A2 is responsible for $\alpha$-synuclein clearance via the lysosome, and a failure in this process would lead to the toxic accumulation of $\alpha$-synuclein in the cytoplasm. miR-595 positively regulates ULK1 thereby inducing autophagy in SH-SY5Y cells, while miR-4487 negatively regulates ULK1 and thus inhibiting autophagy, which may provide potential strategies for PD therapy. 
and selective peptide inhibitor Drp1 inhibitor, P110, increases cell viability by reducing autophagic cell death, and reduced loss of primary dopaminergic neurons in a PD model [35, 122].

Together, most evidence support the cytoprotective role of autophagy in PD, suggesting the potential therapeutic value of promoting autophagy by novel compounds, which is the current research focus. Nevertheless, other PD cases may be associated with autophagic cell death, which makes autophagy block another possible strategy for PD. All in all, to protect dopaminergic cells from death via autophagy modulation is the final goal.

\section{AUTOPHAGY-MODULATING MICRORNAS IN POTENTIAL PD THERAPY}

MicroRNAs (miRNAs), small and non-coding RNA molecules of $22 \sim 24$ nucleotides in length, are involved in a number of homeostatic processes, including cell survival, proliferation, apoptosis and autophagy [123,124]. Several studies have provided links between miRNAs and autophagy modulation. For instance, miR-181A can regulate starvation- and rapamycin-induced autophagy through targeting of ATG5 in MCF-7, Huh-7 and K562 cells [125], and miR-376b controls starvation and mTOR inhibition-related autophagy by targeting ATG4C and Beclin-1 in MCF-7 cells [126]. Furthermore, miRNAs are pathologically altered during the inexorable course of PD, suggesting that miRNAs may also be contributing factors in PD [127,128]. And according to recent studies, the relationships between miRNAs and autophagy in PD have been explored. It is reported that miR-595 positively regulates ULK1 thereby inducing autophagy in SHSY5Y cells, while miR-4487 negatively regulates ULK1 and thus inhibiting autophagy [129], which indicates that autophagy-modulating miRNAs in PD can be explored for potential PD therapeutic purpose. However, investigations on autophagy-modulating miRNAs in PD is just beginning, and some important questions remain to be addressed. Although the identification and validation of miRNA targets has greatly improved, we know little regarding the cellular and molecular circuits in which they are involved. Moreover, there may be a complicated regulatory network of multiple miRNAs and multiple downstream genes. Up to now, studies on miRNAs in $\mathrm{PD}$ is inadequate, and greater attention should be paid to autophagy modulation via miRNAs for potential PD therapy.

\section{CONCLUSIONS}

$\mathrm{PD}$ is one of the most frequent neurodegenerative movement disorders in the world, and many treatment such as medications and surgery are applied in current PD therapy. Modulation of autophagy represent one of novel therapeutic approaches for PD. Recently, it is reported that autophagy plays a pivotal role in the pathogenesis of PD and many PD related proteins are implicated in the regulation of autophagy pathway, such as $\alpha$-synuclein, LRRK2, PINK1 and Parkin. In addition, a number of compounds have been found to alleviate the symptoms of PD via modulation of autophagy. Nevertheless, information about components involved in autophagy in $\mathrm{PD}$ remains limited and functions of some autophagy related components were not confirmed in PD models, which restrains PD therapy targeting autophagy. Currently, most reported compounds that regulate autophagy in PD models target unknown proteins or unknown pathways and specific targets in PD still lack now. Remarkably, it is likely that crucial regulators of autophagy, such as ULK1 and Beclin-1, can be targets for PD drug discovery. It has already been reported that two miRNAs target ULK1 in SH-SY5Y cells and induce or inhibit autophagy. In particular, using new techniques like genomics and proteomics, more new markers and targets in PD will be found, which may shed light on pathogenesis of PD, and also help find potent drugs targeting autophagy for potential therapeutic purpose.

\section{ACKNOWLEDGMENTS}

This work was supported by grants from National Natural Science Foundation of China (Nos. 81260628, 81303270, 81402496 and 81473091).

\section{CONFLICTS OF INTEREST}

The authors declare no conflict of interest.

\section{Author contribution}

Conceived and designed the manuscript: B. Liu and L. Ouyang. Analyzed the data: J.J. Li, S.J. Li and L. Zhang. Wrote the paper: J.J. Li and B. Liu.

\section{REFERENCES}

1. Lees AJ, Hardy J, Revesz T. Parkinson's disease. Lancet. 2009; 373:2055-2066.

2. de Lau LM, Breteler MM. Epidemiology of Parkinson's disease. Lancet Neurol. 2006; 5:525-535.

3. GBD 2013 Mortality and Causes of Death Collaborators. Global, regional, and national age-sex specific all-cause and cause-specific mortality for 240 causes of death, 1990-2013: a systematic analysis for the Global Burden of Disease Study 2013. Lancet. 2015; 385:117-171.

4. Dorsey ER, Constantinescu R, Thompson JP, Biglan KM, 
Holloway RG, Kieburtz K, Marshall FJ, Ravina BM, Schifitto G, Siderowf A, Tanner CM. Projected number of people with Parkinson disease in the most populous nations, 2005 through 2030. Neurology. 2007; 68:384-386.

5. Fahn S. Description of Parkinson's disease as a clinical syndrome. Ann N Y Acad Sci. 2003; 991:1-14.

6. Shulman JM, De Jager PL, Feany MB. Parkinson's disease: genetics and pathogenesis. Annu Rev Pathol. 2011; 6:193222.

7. Damier P, Hirsch EC, Agid Y, Graybiel AM. The substantia nigra of the human brain. II. Patterns of loss of dopaminecontaining neurons in Parkinson's disease. Brain. 1999; 122 (Pt 8):1437-1448.

8. Goetz CG, Pal G. Initial management of Parkinson's disease. BMJ. 2014; 349:g6258.

9. ives-Bauza C, Przedborski S. Mitophagy: the latest problem for Parkinson's disease. Trends Mol Med. 2011; 17:158165.

10. Lynch-Day MA, Mao K, Wang K, Zhao M, Klionsky DJ. The role of autophagy in Parkinson's disease. Cold Spring Harb Perspect Med. 2012; 2:a009357.

11. Huang J, Klionsky DJ. Autophagy and human disease. Cell cycle. 2007 ; 6:1837-1849.

12. Majeski AE, Dice JF. Mechanisms of chaperonemediated autophagy. Int J Biochem Cell Biol. 2004; 36:2435-2444.

13. Kunz JB, Schwarz H, Mayer A. Determination of four sequential stages during microautophagy in vitro. J Biol Chem. 2004; 279:9987-9996.

14. Klionsky DJ. The molecular machinery of autophagy: Unanswered questions. J Cell Sci. 2005; 118:7-18.

15. Winslow AR, Chen CW, Corrochano S, Acevedo-Arozena A, Gordon DE, Peden AA, Lichtenberg M, Menzies FM, Ravikumar B, Imarisio S, Brown S, O'Kane CJ, Rubinsztein DC. alpha-Synuclein impairs macroautophagy: implications for Parkinson's disease. J Cell Biol. 2010; 190:1023-1037.

16. Manzoni C, Mamais A, Dihanich S, Abeti R, Soutar MP, Plun-Favreau H, Giunti P, Tooze SA, Bandopadhyay R, Lewis PA. Inhibition of LRRK2 kinase activity stimulates macroautophagy. Biochim Biophys Acta. 2013; 1833:29002910 .

17. Mercer CA, Kaliappan A, Dennis PB. A novel, human Atg13 binding protein, Atg101, interacts with ULK1 and is essential for macroautophagy. Autophagy. 2009; 5:649-662.

18. Jung CH, Jun CB, Ro SH, Kim YM, Otto NM, Cao J, Kundu M, Kim DH. ULK-Atg13-FIP200 complexes mediate mTOR signaling to the autophagy machinery. Mol Biol Cell. 2009; 20:1992-2003.

19. Jung CH, Ro SH, Cao J, Otto NM, Kim DH. mTOR regulation of autophagy. FEBS Lett. 2010; 584:1287-1295.

20. Kim J, Kundu M, Viollet B, Guan KL. AMPK and mTOR regulate autophagy through direct phosphorylation of Ulk1. Nat Cell Biol. 2011; 13:132-141.

21. Ravikumar B, Futter M, Jahreiss L, Korolchuk VI,
Lichtenberg M, Luo S, Massey DC, Menzies FM, Narayanan U, Renna M, Jimenez-Sanchez M, Sarkar S, Underwood B, Winslow A. Mammalian macroautophagy at a glance. J Cell Sci. 2009; 122:1707-1711.

22. Geng J, Klionsky DJ. The Atg8 and Atg12 ubiquitinlike conjugation systems in macroautophagy. 'Protein modifications: beyond the usual suspects' review series. EMBO Rep. 2008; 9:859-864.

23. Mizushima N, Kuma A, Kobayashi Y, Yamamoto A, Matsubae M, Takao T, Natsume T, Ohsumi Y, Yoshimori T. Mouse Apg16L, a novel WD-repeat protein, targets to the autophagic isolation membrane with the Apg12-Apg5 conjugate. J Cell Sci. 2003; 116:1679-1688.

24. Kabeya Y, Mizushima N, Ueno T, Yamamoto A, Kirisako T, Noda T, Kominami E, Ohsumi Y, Yoshimori T. LC3, a mammalian homologue of yeast Apg8p, is localized in autophagosome membranes after processing. EMBO J. 2000; 19:5720-5728.

25. Klionsky DJ, Baehrecke EH, Brumell JH, Chu CT, Codogno P, Cuervo AM, Debnath J, Deretic V, Elazar Z, Eskelinen EL, Finkbeiner S, Fueyo-Margareto J, Gewirtz D. A comprehensive glossary of autophagy-related molecules and processes (2nd edition). Autophagy. 2011; 7:12731294.

26. Spencer B, Potkar R, Trejo M, Rockenstein E, Patrick C, Gindi R, Adame A, Wyss-Coray T, Masliah E. Beclin 1 gene transfer activates autophagy and ameliorates the neurodegenerative pathology in alpha-synuclein models of Parkinson's and Lewy body diseases. J Neurosci. 2009; 29:13578-13588.

27. Crews L, Spencer B, Desplats P, Patrick C, Paulino A, Rockenstein E, Hansen L, Adame A, Galasko D, Masliah E. Selective molecular alterations in the autophagy pathway in patients with Lewy body disease and in models of alphasynucleinopathy. PloS one. 2010; 5:e9313.

28. Tanji K, Mori F, Kakita A, Takahashi H, Wakabayashi K. Alteration of autophagosomal proteins (LC3, GABARAP and GATE-16) in Lewy body disease. Neurobiol Dis. 2011; 43:690-697.

29. Lachenmayer ML, Yue Z. Genetic animal models for evaluating the role of autophagy in etiopathogenesis of Parkinson disease. Autophagy. 2012; 8:1837-1838.

30. Xiong N, Jia M, Chen C, Xiong J, Zhang Z, Huang J, Hou L, Yang H, Cao X, Liang Z, Sun S, Lin Z, Wang T. Potential autophagy enhancers attenuate rotenone-induced toxicity in SH-SY5Y. Neuroscience. 2011; 199:292-302.

31. Dehay B, Bove J, Rodriguez-Muela N, Perier C, Recasens A, Boya P, Vila M. Pathogenic lysosomal depletion in Parkinson's disease. J Neurosci. 2010; 30:12535-12544.

32. Decressac $M$, Mattsson B, Weikop P, Lundblad M, Jakobsson J, Bjorklund A. TFEB-mediated autophagy rescues midbrain dopamine neurons from alpha-synuclein toxicity. Proc Natl Acad Sci U S A. 2013; 110:E1817-1826.

33. Park HJ, Shin JY, Kim HN, Oh SH, Lee PH. 
Neuroprotective effects of mesenchymal stem cells through autophagy modulation in a parkinsonian model. Neurobiol Aging. 2014; 35:1920-1928.

34. Choubey V, Safiulina D, Vaarmann A, Cagalinec M, Wareski P, Kuum M, Zharkovsky A, Kaasik A. Mutant A53T alpha-synuclein induces neuronal death by increasing mitochondrial autophagy. J Bio Chem. 2011; 286: 1081410824.

35. Su YC, Qi X. Inhibition of excessive mitochondrial fission reduced aberrant autophagy and neuronal damage caused by LRRK2 G2019S mutation. Hum Mol Genet. 2013; 22:4545-4561.

36. Wong AS, Lee RH, Cheung AY, Yeung PK, Chung SK, Cheung ZH, Ip NY. Cdk5-mediated phosphorylation of endophilin B1 is required for induced autophagy in models of Parkinson's disease. Nat Cell Biol. 2011; 13:568-579.

37. Li L, Wang X, Fei X, Xia L, Qin Z, Liang Z. Parkinson's disease involves autophagy and abnormal distribution of cathepsin L. Neurosci Lett. 2011; 489: 62-67.

38. Cheng HC, Kim SR, Oo TF, Kareva T, Yarygina O, Rzhetskaya M, Wang C, During M, Talloczy Z, Tanaka K, Komatsu M, Kobayashi K, Okano H, et al. Akt suppresses retrograde degeneration of dopaminergic axons by inhibition of macroautophagy. J Neurosci. 2011; 31:21252135.

39. Engelender S. alpha-Synuclein fate: proteasome or autophagy? Autophagy. 2012; 8: 418-420.

40. Auluck PK, Caraveo G, Lindquist S. alpha-Synuclein: membrane interactions and toxicity in Parkinson's disease. Annu Rev Cell Dev Biol. 2010; 26:211-233.

41. Polymeropoulos MH, Lavedan C, Leroy E, Ide SE, Dehejia A, Dutra A, Pike B, Root H, Rubenstein J, Boyer R, Stenroos ES, Chandrasekharappa S, Athanassiadou A, et al. Mutation in the alpha-synuclein gene identified in families with Parkinson's disease. Science. 1997; 276:2045-2047.

42. Kruger R, Kuhn W, Muller T, Woitalla D, Graeber M, Kosel S, Przuntek H, Epplen J T, Schols L, Riess O. Ala30Pro mutation in the gene encoding alpha-synuclein in Parkinson's disease. Nat Genet. 1998; 18:106-108.

43. Zarranz JJ, Alegre J, Gomez-Esteban JC, Lezcano E, Ros R, Ampuero I, Vidal L, Hoenicka J, Rodriguez O, Atares B, Llorens V, Gomez Tortosa E, del Ser T, et al. The new mutation, E46K, of alpha-synuclein causes Parkinson and Lewy body dementia. Ann Neurol. 2004; 55:164-173.

44. Chartier-Harlin MC, Kachergus J, Roumier C, Mouroux V, Douay X, Lincoln S, Levecque C, Larvor L, Andrieux J, Hulihan M, Waucquier N, Defebvre L, Amouyel P, et al. Alpha-synuclein locus duplication as a cause of familial Parkinson's disease. Lancet. 2004; 364:1167-1169.

45. Singleton AB, Farrer M, Johnson J, Singleton A, Hague S, Kachergus J, Hulihan M, Peuralinna T, Dutra A, Nussbaum R, Lincoln S, Crawley A, Hanson M, et al. alpha-Synuclein locus triplication causes Parkinson's disease. Science. 2003; 302: 841.
46. Maraganore DM, de Andrade M, Elbaz A, Farrer MJ, Ioannidis JP, Kruger R, Rocca WA, Schneider NK, Lesnick TG, Lincoln SJ, Hulihan MM, Aasly JO, Ashizawa T, et al. Collaborative analysis of alpha-synuclein gene promoter variability and Parkinson disease. JAMA. 2006; 296:661670.

47. Bartels T, Choi JG, Selkoe DJ. alpha-Synuclein occurs physiologically as a helically folded tetramer that resists aggregation. Nature. 2011; 477:107-110.

48. Ebrahimi-Fakhari D, Cantuti-Castelvetri I, Fan Z, Rockenstein E, Masliah E, Hyman B T, McLean PJ, Unni VK. Distinct roles in vivo for the ubiquitin-proteasome system and the autophagy-lysosomal pathway in the degradation of alpha-synuclein. J Neurosci. 2011; 31:14508-14520.

49. Webb JL, Ravikumar B, Atkins J, Skepper JN, Rubinsztein DC. Alpha-Synuclein is degraded by both autophagy and the proteasome. J Bio Chem. 2003; 278:25009-250013.

50. Cuervo AM, Stefanis L, Fredenburg R, Lansbury PT, Sulzer D. Impaired degradation of mutant alpha-synuclein by chaperone-mediated autophagy. Science. 2004; 305:12921295.

51. Stefanis L, Larsen KE, Rideout HJ, Sulzer D, Greene LA. Expression of A53T mutant but not wild-type alphasynuclein in PC12 cells induces alterations of the ubiquitindependent degradation system, loss of dopamine release, and autophagic cell death. J Neurosci. 2001; 21:9549-9560.

52. Xilouri M, Vogiatzi T, Vekrellis K, Stefanis L. alphasynuclein degradation by autophagic pathways: a potential key to Parkinson's disease pathogenesis. Autophagy. 2008; 4:917-919.

53. Ebrahimi-Fakhari D, McLean PJ, Unni VK. Alphasynuclein's degradation in vivo: opening a new (cranial) window on the roles of degradation pathways in Parkinson disease. Autophagy. 2012; 8:281-283.

54. Winslow AR, Chen CW, Corrochano S, Acevedo-Arozena A, Gordon DE, Peden A A, Lichtenberg M, Menzies FM, Ravikumar B, Imarisio S, Brown S, O'Kane CJ, Rubinsztein DC. alpha-Synuclein impairs macroautophagy: implications for Parkinson's disease. J Cell Bio. 2010; 190:1023-1037.

55. Tenreiro S, Reimao-Pinto MM, Antas P, Rino J, Wawrzycka D, Macedo D, Rosado-Ramos R, Amen T, Waiss M, Magalhaes F, Gomes A, Santos CN, Kaganovich D, et al. Phosphorylation modulates clearance of alpha-synuclein inclusions in a yeast model of Parkinson's disease. PLoS Genet. 2014; 10: e1004302

56. Winslow AR, Rubinsztein DC. The Parkinson disease protein alpha-synuclein inhibits autophagy. Autophagy. 2011; 7:429-431.

57. Tanik SA, Schultheiss CE, Volpicelli-Daley LA, Brunden KR, Lee VM. Lewy body-like alpha-synuclein aggregates resist degradation and impair macroautophagy. J Cell Bio. 2013; 288:15194-15210.

58. Chen L, Xie Z, Turkson S, Zhuang X. A53T human 
$\alpha$-synuclein overexpression in transgenic mice induces pervasive mitochondria macroautophagy defects preceding dopamine neuron degeneration. J Neurosci. 2015 21; 35:890-905.

59. Devi L, Raghavendran V, Prabhu BM, Avadhani NG, Anandatheerthavarada HK. Mitochondrial import and accumulation of alpha-synuclein impair complex I in human dopaminergic neuronal cultures and Parkinson disease brain. J Biol Chem .2008; 283:9089-9100.

60. Nakamura K, Nemani VM, Azarbal F, Skibinski G, Levy JM, Egami K, MunishkinaL, Zhang J, Gardner B, Wakabayashi J, Sesaki H, Cheng Y, Finkbeiner S, et al. Direct membrane association drives mitochondrial fission by the Parkinson disease-associated protein alphasynuclein. J Biol Chem .2011; 286:20710-20726.

61. Bendor JT, Logan TP, Edwards RH. The function of alphasynuclein. Neuron. 2013; 79:1044-1066.

62. Jiang TF, Zhang YJ, Zhou HY, Wang HM, Tian LP, Liu J, Ding JQ, Chen SD. Curcumin ameliorates the neurodegenerative pathology in A53T $\alpha$-synuclein cell model of Parkinson's disease through the downregulation of $\mathrm{mTOR} / \mathrm{p} 70 \mathrm{~S} 6 \mathrm{~K}$ signaling and the recovery of macroautophagy. J Neuroimmune Pharm. 2013; 8:356-369.

63. Yan JQ, Yuan YH, Gao YN, Huang JY, Ma KL, Gao Y, Zhang WQ, Guo XF, Chen NH. Overexpression of human E46K mutant $\alpha$-synuclein impairs macroautophagy via inactivation of JNK1-Bcl-2 pathway. Mol Neurobiol. 2014; 50:685-701.

64. Gilks WP, Abou-Sleiman PM, Gandhi S, Jain S, Singleton A, Lees AJ, Shaw K, Bhatia KP, Bonifati V, Quinn NP, Lynch J, Healy DG, Holton JL, et al. A common LRRK2 mutation in idiopathic Parkinson's disease. Lancet. 2005; 365: 415-416.

65. Verstraeten A, Theuns J, Van Broeckhoven C. Progress in unraveling the genetic etiology of Parkinson disease in a genomic era. Trends Genet. 2015; 31: 140-149.

66. Cookson MR. The role of leucine-rich repeat kinase 2 (LRRK2) in Parkinson's disease. Nature reviews. Neuroscience. 2010; 11:791-797.

67. Aasly JO, Vilarino-Guell C, Dachsel JC, Webber PJ, West AB, Haugarvoll K, Johansen KK, Toft M, Nutt JG, Payami H, Kachergus JM, Lincoln SJ, Felic A, et al. Novel pathogenic LRRK2 p.Asn1437His substitution in familial Parkinson's disease. Mov Disord : official journal of the Movement Disorder Society. 2010; 25:2156-2163.

68. Rudenko IN, Cookson MR. Heterogeneity of leucinerich repeat kinase 2 mutations: genetics, mechanisms and therapeutic implications. Neurotherapeutics. 2014; 11: 738750 .

69. Tong Y, Yamaguchi H, Giaime E, Boyle S, Kopan R, Kelleher RJ 3rd, Shen J. Loss of leucine-rich repeat kinase 2 causes impairment of protein degradation pathways, accumulation of alpha-synuclein, and apoptotic cell death in aged mice. Proc Natl Acad Sci U S A. 2010; 107:9879-
9884.

70. Schapansky J, Nardozzi JD, Felizia F, LaVoie MJ. Membrane recruitment of endogenous LRRK2 precedes its potent regulation of autophagy. Hum Mol Genet. 2014; 23: 4201-4214.

71. Alegre-Abarrategui J, Christian H, Lufino MM, Mutihac R, Venda LL, Ansorge O, Wade-Martins R. LRRK2 regulates autophagic activity and localizes to specific membrane microdomains in a novel human genomic reporter cellular model. Hum Mol Genet. 2009; 18:4022-4034.

72. Plowey ED, Cherra SJ, Liu YJ, Chu CT. Role of autophagy in G2019S-LRRK2-associated neurite shortening in differentiated SH-SY5Y cells. J Neurochem. 2008; 105:1048-1056.

73. Wang X, Yan MH, Fujioka H, Liu J, Wilson-Delfosse A, Chen SG, Perry G, Casadesus G, Zhu X. LRRK2 regulates mitochondrial dynamics and function through direct interaction with DLP1. Hum Mol Genet. 2012; 21:19311944.

74. Saha S, Ash PE, Gowda V, Liu L, Shirihai O, Wolozin B. Mutations in LRRK2 potentiate age-related impairment of autophagic flux. Mol Neurodegener. 2015; 10: 26.

75. Su YC, Guo X, Qi X. Threonine 56 phosphorylation of Bcl2 is required for LRRK2 G2019S-induced mitochondrial depolarization and autophagy. Biochim Biophys Acta. 2015; 1852:12-21.

76. Reinhardt P, Schmid B, Burbulla LF, Schondorf DC, Wagner L, Glatza M, Hoing S, Hargus G, Heck SA, Dhingra A, Wu G, Muller S, Brockmann K, et al. Genetic correction of a LRRK2 mutation in human iPSCs links parkinsonian neurodegeneration to ERK-dependent changes in gene expression. Cell stem cell. 2013; 12:354-367.

77. Nguyen HN, Byers B, Cord B, Shcheglovitov A, Byrne J, Gujar P, Kee K, Schule B, Dolmetsch RE, Langston W, Palmer TD, Pera RR. LRRK2 mutant iPSC-derived DA neurons demonstrate increased susceptibility to oxidative stress. Cell stem cell. 2011; 8: 267-280.

78. Skibinski G, Nakamura K, Cookson MR, Finkbeiner S. Mutant LRRK2 toxicity in neurons depends on LRRK2 levels and synuclein but not kinase activity or inclusion bodies. J Neurosci. 2014; 34:418-433.

79. Daher JP, Volpicelli-Daley LA, Blackburn JP, Moehle MS, West AB. Abrogation of alpha-synuclein-mediated dopaminergic neurodegeneration in LRRK2-deficient rats. Proc Natl Acad Sci U S A. 2014; 111: 9289-9294.

80. Lin X, Parisiadou L, Gu XL, Wang L, Shim H, Sun L, Xie C, Long CX, Yang WJ, Ding J, Chen ZZ, Gallant PE, TaoCheng $\mathrm{JH}$, et al. Leucine-rich repeat kinase 2 regulates the progression of neuropathology induced by Parkinson'sdisease-related mutant alpha-synuclein. Neuron. 2009; 64:807-827.

81. Houlden H, Singleton AB. The genetics and neuropathology of Parkinson's disease. Acta Neuropathol 2012; 124:325338. 
82. Hristova VA, Beasley SA, Rylett RJ, Shaw GS. Identification of a novel $\mathrm{Zn} 2+$-binding domain in the autosomal recessive juvenile Parkinson-related E3 ligase parkin. J Bio Chem. 2009; 284:14978-14986.

83. Shimura H, Hattori N, Kubo S, Mizuno Y, Asakawa S, Minoshima S, Shimizu N, Iwai K, Chiba T, Tanaka K, Suzuki T. Familial Parkinson disease gene product, parkin, is a ubiquitin-protein ligase. Nat Genet. 2000; 25:302-305.

84. Hattori N, Kitada T, Matsumine H, Asakawa S, Yamamura Y, Yoshino H, Kobayashi T, Yokochi M, Wang M, Yoritaka A, Kondo T, Kuzuhara S, Nakamura S, et al. Molecular genetic analysis of a novel Parkin gene in Japanese families with autosomal recessive juvenile parkinsonism: evidence for variable homozygous deletions in the Parkin gene in affected individuals. Ann Neurol. 1998; 44: 935-941.

85. Hedrich K, Marder K, Harris J, Kann M, Lynch T, MeijaSantana H, Pramstaller PP, Schwinger E, Bressman SB, Fahn S, Klein C. Evaluation of 50 probands with earlyonset Parkinson's disease for Parkin mutations. Neurology. 2002; 58:1239-1246.

86. Khan NL, Graham E, Critchley P, Schrag AE, Wood NW, Lees AJ, Bhatia KP, Quinn N. Parkin disease: a phenotypic study of a large case series. Brain. 2003; 126: 1279-1292.

87. Kann M, Jacobs H, Mohrmann K, Schumacher K, Hedrich K, Garrels J, Wiegers K,S chwinger E, Pramstaller PP, Breakefield XO, Ozelius LJ, Vieregge P, Klein C. Role of parkin mutations in 111 community-based patients with early-onset parkinsonism. Ann Neurol. 2002; 51:621-625.

88. Valente EM, Bentivoglio AR, Dixon PH, Ferraris A, Ialongo T, Frontali M, Albanese A, Wood NW. Localization of a novel locus for autosomal recessive early-onset parkinsonism, PARK6, on human chromosome 1p35-p36. Am J Hum Genet. 2001; 68: 895-900.

89. Pickrell AM, Youle RJ. The roles of PINK1, parkin, and mitochondrial fidelity in Parkinson's disease. Neuron. 2015; 85: 257-273.

90. Li Y, Tomiyama H, Sato K, Hatano Y, Yoshino H, Atsumi M, Kitaguchi M, Sasaki S, Kawaguchi S, Miyajima H, Toda T, Mizuno Y.,Hattori N. Clinicogenetic study of PINK1 mutations in autosomal recessive early-onset parkinsonism. Neurology. 2005; 64: 1955-1957.

91. Rohe CF, Montagna P, Breedveld G, Cortelli P, Oostra BA, Bonifati V. Homozygous PINK1 C-terminus mutation causing early-onset parkinsonism. Ann Neurol. 2004; 56: 427-431.

92. Hedrich K, Hagenah J, Djarmati A, Hiller A, Lohnau T, Lasek K, Grunewald A, Hilker R, Steinlechner S, Boston H, Kock N, Schneider-Gold C, Kress W, et al. Clinical spectrum of homozygous and heterozygous PINK1 mutations in a large German family with Parkinson disease: role of a single hit? Arch Neurol. 2006; 63:833-838.

93. Ibanez P, Lesage S, Lohmann E, Thobois S, De Michele G, Borg M, Agid Y, Durr A, Brice A, French Parkinson's Disease Genetics Study G. Mutational analysis of the
PINK1 gene in early-onset parkinsonism in Europe and North Africa. Brain. 2006; 129: 686-694.

94. Vives-Bauza C, Zhou C, Huang Y, Cui M, de Vries RL, Kim J, May J, Tocilescu MA, Liu W, Ko HS, Magrane J, Moore DJ, Dawson VL, et al. PINK1-dependent recruitment of Parkin to mitochondria in mitophagy. Proc Natl Acad Sci U S A. 2010; 107:378-383.

95. Michiorri S, Gelmetti V, Giarda E, Lombardi F, Romano F, Marongiu R, Nerini-Molteni S, Sale P, Vago R, Arena G, Torosantucci L, Cassina L, Russo MA, et al. The Parkinsonassociated protein PINK1 interacts with Beclin1 and promotes autophagy. Cell Death Differ. 2010; 17:962-974.

96. Arena G, Gelmetti V, Torosantucci L, Vignone D, Lamorte G, De Rosa P, Cilia E, Jonas EA, Valente EM. PINK1 protects against cell death induced by mitochondrial depolarization, by phosphorylating Bcl-xL and impairing its pro-apoptotic cleavage. Cell Death Differ. 2013; 20:920930.

97. Krebiehl G, Ruckerbauer S, Burbulla LF, Kieper N, Maurer B, Waak J, Wolburg H, Gizatullina Z, Gellerich FN, Woitalla D, Riess O, Kahle PJ, Proikas-Cezanne T, et al. Reduced basal autophagy and impaired mitochondrial dynamics due to loss of Parkinson's disease-associated protein DJ-1. PloS one. 2010; 5:e9367.

98. Gonzalez-Polo R, Niso-Santano M, Moran JM, OrtizOrtiz MA, Bravo-San Pedro J M, Soler G, Fuentes JM. Silencing DJ-1 reveals its contribution in paraquat-induced autophagy. J Neurochem. 2009; 109:889-898.

99. Irrcher I, Aleyasin H, Seifert EL, Hewitt SJ, Chhabra S, Phillips M, Lutz AK, Rousseaux MW, Bevilacqua L, Jahani-Asl A, Callaghan S, MacLaurin JG, Winklhofer $\mathrm{KF}$, et al. Loss of the Parkinson's disease-linked gene DJ-1 perturbs mitochondrial dynamics. Hum Mol Genet. 2010; 19:3734-3746.

100. Thomas KJ, McCoy MK, Blackinton J, Beilina A, van der Brug M, Sandebring, A, Miller D, Maric D, CedazoMinguez A, Cookson MR. DJ-1 acts in parallel to the PINK1/parkin pathway to control mitochondrial function and autophagy. Hum Mol Genet. 2011; 20:40-50.

101. Vasseur S, Afzal S, Tardivel-Lacombe J, Park DS, Iovanna JL, Mak TW. DJ-1/PARK7 is an important mediator of hypoxia-induced cellular responses. Proc Natl Acad Sci U S A. 2009; 106:1111-1116.

102. McCoy MK, Cookson MR. DJ-1 regulation of mitochondrial function and autophagy through oxidative stress. Autophagy. 2011; 7:531-532.

103. Ren H, Fu K, Mu C, Li B, Wang D, Wang G. DJ-1, a cancer and Parkinson's disease associated protein, regulates autophagy through JNK pathway in cancer cells. Cancer Lett. 2010; 297:101-108.

104. Kabuta T, Furuta A, Aoki S, Furuta K, Wada K. Aberrant interaction between Parkinson disease-associated mutant UCH-L1 and the lysosomal receptor for chaperonemediated autophagy. J Bio Chem. 2008; 283: 23731-23738. 
105. Pukass K, Richter-Landsberg C. Inhibition of UCH-L1 in oligodendroglial cells results in microtubule stabilization and prevents alpha-synuclein aggregate formation by activating the autophagic pathway: implications for multiple system atrophy. Front Cell Neurosci. 2015; 9:163.

106. Ramirez A, Heimbach A, Grundemann J, Stiller B, Hampshire D, Cid LP, Goebel I, Mubaidin AF, Wriekat AL, Roeper J, Al-Din A, Hillmer AM, Karsak M, et al. Hereditary parkinsonism with dementia is caused by mutations in ATP13A2, encoding a lysosomal type 5 P-type ATPase. Nat Genet. 2006; 38:1184-1191.

107. Kong SM, Chan BK, Park JS, Hill KJ, Aitken JB, Cottle L, Farghaian H, Cole AR, Lay PA, Sue CM, Cooper AA. Parkinson's disease-linked human PARK9/ATP13A2 maintains zinc homeostasis and promotes alpha-Synuclein externalization via exosomes. Hum Mol Genet. 2014; 23:2816-2833.

108. Dehay B, Martinez-Vicente M, Ramirez A, Perier C, Klein C, Vila M, Bezard E. Lysosomal dysfunction in Parkinson disease: ATP13A2 gets into the groove. Autophagy. 2012; 8:1389-1391.

109. Beavan MS, Schapira AH. Glucocerebrosidase mutations and the pathogenesis of Parkinson disease. Ann Med. 2013; 45:511-521.

110. Murphy KE, Gysbers AM, Abbott SK, Tayebi N, Kim WS, Sidransky E, Cooper A, Garner B, Halliday GM. Reduced glucocerebrosidase is associated with increased alphasynuclein in sporadic Parkinson's disease. Brain. 2014; 137:834-848.

111. Valadas JS, Vos M, Verstreken P. Therapeutic strategies in Parkinson's disease: what we have learned from animal models. Annals of the New York Academy of Sciences. 2015; 1338:16-37.

112. Pan T, Kondo S, Zhu W, Xie W, Jankovic J, Le W. Neuroprotection of rapamycin in lactacystin-induced neurodegeneration via autophagy enhancement. Neurobiology of disease. 2008; 32:16-25.

113. Hollerhage M, Goebel JN, de Andrade A, Hildebrandt T, Dolga A, Culmsee C, Oertel WH, Hengerer B, Hoglinger GU. Trifluoperazine rescues human dopaminergic cells from wild-type alpha-synuclein-induced toxicity. Neurobiology of aging. 2014; 35:1700-1711.

114. ZhangL, Yu J, Pan H, Hu P, Hao Y, Cai W, Zhu H, Yu AD, Xie X, Ma D,Yuan J. Small molecule regulators of autophagy identified by an image-based high-throughput screen. Proceedings of the National Academy of Sciences of the United States of America. 2007; 104:19023-19028.

115. Sarkar S, Davies JE, Huang Z, Tunnacliffe A, Rubinsztein DC. Trehalose, a novel mTOR-independent autophagy enhancer, accelerates the clearance of mutant huntingtin and alpha-synuclein. The Journal of biological chemistry. 2007; 282:5641-5652.

116. Savolainen MH, Richie CT, Harvey BK, Mannisto PT, Maguire-Zeiss KA, Myohanen TT. The beneficial effect of a prolyl oligopeptidase inhibitor, KYP-2047, on alphasynuclein clearance and autophagy in A30P transgenic mouse. Neurobiology of disease. 2014; 68:1-15.

117. Savolainen MH, Yan X, Myohanen TT, Huttunen HJ. Prolyl oligopeptidase enhances alpha-synuclein dimerization via direct protein-protein interaction. The Journal of biological chemistry. 2015; 290:5117-5126.

118. Hebron ML, Lonskaya I, Moussa CE. Nilotinib reverses loss of dopamine neurons and improves motor behavior via autophagic degradation of alpha-synuclein in Parkinson's disease models. Human molecular genetics. 2013; 22:33153328.

119. Steele JW, Ju S, Lachenmayer ML, Liken J, Stock A, Kim SH, Delgado LM, Alfaro IE, Bernales S, Verdile G, Bharadwaj P, Gupta V, Barr R, et al. Latrepirdine stimulates autophagy and reduces accumulation of alpha-synuclein in cells and in mouse brain. Molecular psychiatry. 2013; 18:882-888.

120. Shen W, Henry AG, Paumier KL, Li L, Mou K, Dunlop J, Berger Z, Hirst WD. Inhibition of glucosylceramide synthase stimulates autophagy flux in neurons. Journal of neurochemistry. 2014; 129:884-894.

121. Saez-Atienzar S, Bonet-Ponce L, Blesa JR, Romero, FJ, Murphy MP, Jordan J, Galindo MF. The LRRK2 inhibitor GSK2578215A induce protective autophagy in SH-SY5Y cells: involvement of Drp-1-mediated mitochondrial fission and mitochondrial-derived ROS signaling. Cell Death Dis. 2014; 5:e1368.

122. Qi X, Qvit N, Su YC, Mochly-Rosen D. A novel Drp1 inhibitor diminishes aberrant mitochondrial fission and neurotoxicity. Journal of cell science. 2013; 126: 789-802.

123. Fu LL, Wen X, Bao JK, Liu B. MicroRNA-modulated autophagic signaling networks in cancer. The International Journal of Biochemistry \& Cell Biology. 2012; 44:733-736.

124. Chen Y, Fu LL, Wen X, Liu B, Huang J, Wang JH, Wei YQ. Oncogenic and tumor suppressive roles of microRNAs in apoptosis and autophagy. Apoptosis. 2014; 19: 11771189.

125. Tekirdag KA, Korkmaz G, Ozturk DG, Agami R, Gozuacik D. MIR181A regulates starvation- and rapamycin-induced autophagy through targeting of ATG5. Autophagy. 2013; 9:374-385.

126. Korkmaz G, le Sage C, Tekirdag KA, Agami R, Gozuacik D. miR-376b controls starvation and mTOR inhibitionrelated autophagy by targeting ATG4C and BECN1. Autophagy. 2012; 8:165-176.

127. Tan L, Yu JT, Tan L. Causes and Consequences of MicroRNA Dysregulation in Neurodegenerative Diseases. Mol Neurobiol. 2014; 51:1249-1262.

128. Cheung ZH, Ip NY. Autophagy deregulation in neurodegenerative diseases-recent advances and future perspectives. J Neurochem. 2011; 118:317-325.

129. Chen Y, Wang S, Zhang L, Xie T, Song S, Huang J, Zhang Y, Ouyang L, Liu B. Identification of ULK1 as a novel 
biomarker involved in miR-4487 and miR-595 regulation in neuroblastoma SH-SY5Y cell autophagy. Sci Rep. 2015; 5:11035. 